\title{
Spinal Interneurons as Gatekeepers to Neuroplasticity after Injury or Disease
}

\author{
${ }^{\circledR}$ Lyandysha V. Zholudeva, ${ }^{1}{ }^{\circledR}$ Victoria E. Abraira, ${ }^{2}{ }^{\circledR}$ Kajana Satkunendrarajah, ${ }^{3,4}{ }^{\circledR}$ Todd C. McDevitt, ${ }^{1,5}$ \\ ${ }^{\circledR}$ Martyn D. Goulding, ${ }^{6}{ }^{\circledR}$ David S. K. Magnuson, ${ }^{7}$ and ${ }^{\circledR}$ Michael A. Lane ${ }^{8}$ \\ ${ }^{1}$ Gladstone Institutes, San Francisco, California, $94158,{ }^{2}$ Department of Cell Biology \& Neuroscience, Rutgers University, The State University of \\ New Jersey, New Jersey, 08854, ${ }^{3}$ Departments of Neurosurgery and Physiology, Medical College of Wisconsin, Wisconsin, 53226, ${ }^{4}$ Clement J. \\ Zablocki Veterans Affairs Medical Center, Milwaukee, Wisconsin, 53295, ${ }^{5}$ Department of Bioengineering and Therapeutic Sciences, University of \\ California, San Francisco, California, 94143, ${ }^{6}$ Salk Institute for Biological Sciences, La Jolla, California, 92037, ${ }^{7}$ University of Louisville, Kentucky \\ Spinal Cord Injury Research Center, Louisville, Kentucky, 40208, and ${ }^{8}$ Department of Neurobiology and Anatomy, and the Marion Murray Spinal \\ Cord Research Center, Drexel University, Philadelphia, Pennsylvania, 19129
}

Spinal interneurons are important facilitators and modulators of motor, sensory, and autonomic functions in the intact CNS. This heterogeneous population of neurons is now widely appreciated to be a key component of plasticity and recovery. This review highlights our current understanding of spinal interneuron heterogeneity, their contribution to control and modulation of motor and sensory functions, and how this role might change after traumatic spinal cord injury. We also offer a perspective for how treatments can optimize the contribution of interneurons to functional improvement.

Key words: interneuron; plasticity; propriospinal; spinal cord

\section{Introduction}

Some of the earliest documentation of cellular heterogeneity in the nervous system dates back to the 19th century when the pioneering studies by Ramon y Cajal characterized the vast diversity, complexity, and morphologic heterogeneity of the nervous system (Ramon y Cajal et al., 1995). Building on these data, Sir Charles Sherrington contributed to the classification of spinal cellular phenotypes with his work in canines, describing populations of spinal cells connecting multiple spinal cord segments that play a role in essential motor reflexes (Sherrington and Laslett, 1903a,b). These propriospinal neurons were further characterized via classical electrophysiology experiments, which provided evidence of long descending projections connecting cervical propriospinal neurons to lumbosacral motor pools (Lloyd, 1942; Lloyd and McIntyre, 1948). The overall structural organization and morphologic heterogeneity of the spinal cord were further elaborated by Rexed $(1952,1954)$, who used classical histologic methods to describe the anatomic distribution of spinal neurons classified by their size and shape and delineated the anatomic structure into

\footnotetext{
Received June 30, 2020; revised Dec. 15, 2020; accepted Dec. 17, 2020.

This work was supported by the Lisa Dean Moseley Foundation to L.V.Z;; Pew Charitable Trust, Whitehall Foundation, and New Jersey Commission on Spinal Cord Research to V.E.A.; Craig H. Neilsen 649984 to K.S.; Roddenberry Foundation and Stuart M. Gordon to T.C.M.; National Institutes of Health NS111643 and NS112959, and Frederick W. and Joanne J. Mitchell Chair in Molecular Biology to M.D.G.; National Institutes of Health R01 NS089324 and Kentucky Spinal Cord and Head Injury Research Trust to D.S.K.M.; and National Institutes of Health R01 NS104291, Lisa Dean Moseley Foundation, Wings for Life Spinal Cord Research Foundation, and Craig H. Neilsen 465068 to M.A.L. We thank Drs. llya Rybak and Simon Danner (Drexel University) for comments on the section, Synaptic silencing of SplNs reveals context-dependent locomotor hierarchies.

The authors declare no competing financial interests.

Correspondence should be addressed to Lyandysha V. Zholudeva at Lana.Zholudeva@gladstone.ucsf.edu or Michael A. Lane at mlane.neuro@gmail.com.

https://doi.org/10.1523/JNEUROSCI.1654-20.2020

Copyright $\odot 2021$ the authors
}

dorsoventral "laminae" in the cat. With some effort over time, these laminae were associated with identifiable functions.

The spinal cord is comprised of two main types of neuronal populations: spinal interneurons (SpINs) and projection neurons. Projection neurons are those with the cell body within the spinal cord, but projections outside the spinal cord (either to other parts of CNS or periphery). SpINs are cells within the spinal cord that project to other cells within the spinal cord. SpINs comprise a vast range of neuronal types with unique properties and connectivity. These include (1) long and short propriospinal neurons, with ascending and descending projections; and (2) local SpINs with projections on the same side (ipsilateral) and/or that cross the spinal midline (commissural).

While anatomic studies were initially limited to general histologic or ultrastructural assessment, the development of transneuronal tracing (e.g., with pseudorabies virus) led to the identification of vast populations of SpINs integrated with motor, sensory, and autonomic networks. In addition, these approaches revealed neuroplastic changes within the connectivity of SpINs, and identified phenotypic subsets that may contribute to plasticity after traumatic spinal cord injury (SCI). Transgenic models have enabled developmental neurobiologists to better define populations of SpINs and their contribution to network function.

This review focuses on some of the recent discoveries that have propelled our understanding of the spinal cord as a site of convergence, divergence, and processing of multiple avenues of information, as well as revealing the rich anatomic and functional diversity of SpINs and their neuroplastic and therapeutic potential.

\footnotetext{
Molecular characterization of SpINs: from development to function

In the past few decades, developmental neurobiology has offered unique and important insights into the identity of progenitor cell
} 
types that contribute to SpIN classification. Genetic manipulations have enabled scientists to establish "cardinal classes" of spinal neurons, visualize their migration and connectivity, and define their specific roles in motor and sensory networks (for review, see (Goulding, 2009; Kiehn, 2016; Lai et al., 2016). The use of transcription factors expressed during development has helped define spinal neuron populations, but linking embryonic lineage with mature progeny has proved more difficult. Thus, genetic tools are being combined with other complementary approaches, including morphology, electrophysiology, and connectivity, to define cell phenotype (Fig. 1). These tremendous efforts have increased our understanding of the general diversity of interneurons, particularly within the ventrally (V0-V3) and dorsally (dIs) derived classes. Detailed overviews of the interneuronal classes and subclasses were provided previously (Dougherty and Kiehn, 2010b; Alaynick et al., 2011; Lu et al., 2015; Rybak et al., 2015; Flynn et al., 2017; Zholudeva et al., 2018a; Dobrott et al., 2019). Here, we draw on a few select populations of ventrally derived neurons to provide examples of heterogeneity and of the contributions SpINs make to spinal circuit function.

The integration of multidisciplinary approaches has allowed researchers to divide major classes of interneurons into finer subtypes and to investigate their roles in disease. For example, the V0 class of interneurons is now divided into at least four subpopulations (Fig. 1) (Lanuza et al., 2004; Zagoraiou et al., 2009; Talpalar et al., 2013). A recent study demonstrated that large cholinergic synapses on motoneurons (most likely the V0c interneurons) (Rozani et al., 2019) could contribute to aberrant excitation during amyotrophic lateral sclerosis progression (Konsolaki et al., 2020).

The inhibitory (GABA/glycine) V1 class of SpINs, which express the homeodomain transcription factor Engrailed-1, comprise more than a dozen distinct neuronal subpopulations, categorized into four major groups based on the expression of 19 transcription factors (Bikoff et al., 2016; Gabitto et al., 2016; Sweeney et al., 2018). Transcriptionally distinct groups of V1 interneurons diverge in their physiological properties, display neuronal input specificity (e.g., from sensory vs motor neurons), and form inhibitory microcircuits that are tailored to individual limb muscles. V1 subpopulations are also divergent in their rostrocaudal positioning along the neural axis, corresponding with limb and thoracic motor output, and segmentally specified by their Hox gene expression profile (Sweeney et al., 2018). Studies by the Goulding research team have used mouse genetics to explore the role of V1 interneurons in locomotion. In addition to altering the speed of the step cycle (Gosgnach et al., 2006), deletion of $\mathrm{V} 1$ interneurons results in prolonged activation (disinhibition) of motoneurons innervating flexor muscles, disrupting the stereotypical flexor-extensor phases of contraction during locomotion (Britz et al., 2015). In addition, a recent study using the $\mathrm{SOD}^{\mathrm{G} 93 \mathrm{~A}}$ mouse model of amyotrophic lateral sclerosis detailed motoneuron innervation by $\mathrm{V} 1$ subtypes and demonstrated the susceptibility of these connections to degeneration over time. The work included an elaborate model of progressive upregulation (e.g., compensatory plasticity) in V1 synaptic connectivity before breakdown of interneuronal circuits (Salamatina et al., 2020).

The V2 class of SpINs, located within the intermediate-ventral gray matter, is divided into excitatory (V2a) and inhibitory (V2b) subclasses. Much like the V1 neurons, V2b interneurons have been associated with inhibition of motoneuron output, primarily in the context of flexor-extensor coordination during locomotion. Whereas the loss of V1 interneurons results in prolonged flexion, the loss of the V2b subclass results in prolonged hyperextension (Britz et al., 2015). More recently, the V2b interneurons have been shown to play a role in speed of locomotion (Callahan et al., 2019). In contrast, the V2a interneurons are an ipsilaterally projecting, excitatory population of rhythmically active (Dougherty and Kiehn, 2010a,b; Zhong et al., 2010) premotor cells, implicated in left-right coordination. In addition to their role in locomotion, the V2a SpINs have recently been shown to be integrated with spinal respiratory networks, and to contribute to plasticity in models of SCI (Zholudeva et al., 2017; Jensen et al., 2019b) and amyotrophic lateral sclerosis (Romer et al., 2016).

While much of what we have learned about SpINs has come from studying lumbar spinal networks and locomotor function, ongoing research is now highlighting roles for interneuronal subtypes in other motor (e.g., skilled reaching, respiratory) and sensory (e.g., pain, itch) functions. These diverse roles are being explored in both the intact spinal cord (for review, see Zholudeva et al., 2018a; Dobrott et al., 2019) and in models of injury (Zholudeva et al., 2017; Jensen et al., 2019a) and disease (Romer et al., 2016). While in general terms, the ventrally derived neurons can be thought of as premotor, and more dorsally derived cells as sensory-related, this is an oversimplification, and motor and sensory functions are closely interlinked. 


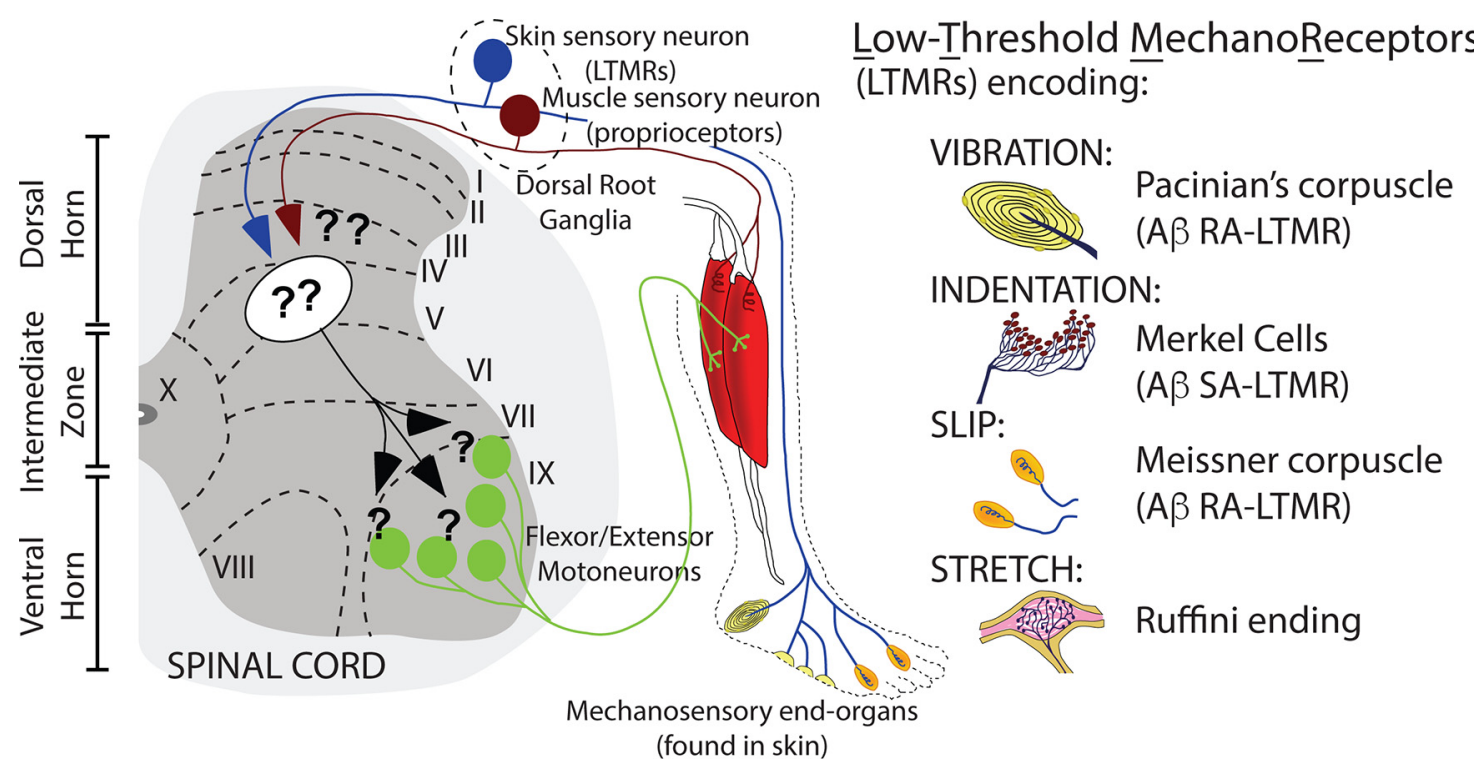

Figure 2. The intermediate spinal cord receives convergent information from proprioceptors (innervating muscles) and cutaneous receptors located on the soles of feet and joints (also known as low-threshold mechanoreceptors [LTMRs]). Current efforts are centered on understanding the functional logic of the spinal cord networks that bridge cutaneous/proprioceptive sensory information with motor centers of the spinal cord ventral horn and how these contribute to SCI recovery. RA, rapidly adapting; SA, slowly adapting; I-X, Rexed laminae I-X.

The "cardinal class" description of interneurons has been useful for broadly describing neuronal subtypes. However, identifying the diversity that exists within each class requires a battery of measures, including genetic marker expression, morphologic characteristics, electrophysiological signatures, and network connectivity. For example, a combination of morphology, electrophysiology, and functional analysis has been used to show that the V1 interneuron population is composed of multiple cell types, including Renshaw cells and Ia inhibitory interneurons (Sapir et al., 2004; Alvarez et al., 2005; J. Zhang et al., 2014). Likewise, the recent study by Abraira et al. (2017) used genetic tools to label and probe 11 dorsal horn neuronal populations, describing their location, morphology, connectivity, and electrophysiological properties. This study aligned multiple cellular features, thereby providing an indepth understanding of interneuronal diversity within the dorsal horn.

\section{Spinal interneuron diversity: beyond the cardinal classes}

Defining each progenitor domain as a unique entity is organizationally simplistic, but recent single-cell RNA sequencing studies have begun to challenge this categorization of cell populations (Haring et al., 2018; Rosenberg et al., 2018; Sathyamurthy et al., 2018; Delile et al., 2019). These studies highlighted the difficulty in limiting classification to the cardinal classes. For instance, while cardinal classifications may be appropriate for some dorsal interneurons, the ventral populations of SpINs have been found to have overlapping gene expression profiles as the animal matures. Greater attention to SpIN heterogeneity across the rostrocaudal axis has also shed light on these differences. For instance, differences have been detected in both the V1 (Sweeney et al., 2018) and V2a (Hayashi et al., 2018) populations along the neural axis. At present, the cardinal class categorization also excludes some of the locomotor rhythmgenerating neurons. Two examples include the Shox 2 expressing non-V2a SpINs (Dougherty et al., 2013) and the Hb9expressing Vx SpINs (Brownstone and Wilson, 2008; Caldeira et al., 2017). Combining RNA sequencing with a range of other assessments (e.g., behavioral activity) (Sathyamurthy et al., 2018) or spinal stimulation (Skinnider et al., 2020) will continue to provide the most rigorous assessment of interneuronal phenotype classification.

\section{Ongoing research perspectives}

Interpreting the functional consequences of SCI (and compromised spinal networks) and the progressive neuroplastic changes that follow requires a better understanding of how SpINs facilitate and modulate function normally, how they adapt to changing functional requirements (context dependency), and how networks of interneurons spontaneously adapt to SCI. The following sections highlight work being done by the Goulding, Abraira, Satkunendrarajah, and Magnuson research teams, then describe how SpINs have been therapeutically targeted, offering examples of how the field of spinal cord neurobiology is advancing to further appreciate the diversity, functional importance, and therapeutic relevance of SpINs.

\section{Touching on locomotion: an anatomical and functional} analysis of spinal cord neurons that shape the way we move The spinal cord integrates proprioceptive, touch and nociceptive input to shape motor output. Our increased understanding of how spinal cord circuits integrate multiple sensory modalities has helped to improve rehabilitative therapies for SCI. Since Sherrington's pioneering work on the proprioceptive reflex pathway (Burke, 2007), great progress has been made in understanding how proprioceptors (i.e., muscle sensory neurons) shape motor activity, in particular locomotion (Grillner and Rossignol, 1978; Pearson and Rossignol, 1991; Hiebert et al., 1996; Lam and Pearson, 2001; Akay et al., 2014). Touch receptors in skin that encode sensory modalities, such as vibration, indentation, and slip, are also critical for adapting locomotion to changes in our environment, and they have begun to be recognized as an important component for rehabilitation-based recovery after SCI (Fig. 2) (Sławińska et al., 2012; Bui and Brownstone, 2015; Bui et al., 2015). How the spinal cord integrates touch information to sculpt motor activity is poorly understood. Nonetheless, progress is now being made by drawing on an ever-expanding mouse 
genetic toolbox to visualize, quantify, and manipulate touch-specific spinal cord circuits (Li et al., 2011; Abraira and Ginty, 2013; Bourane et al., 2015; Rutlin et al., 2015; Abraira et al., 2017; Gatto et al., 2020). Leveraging these powerful genetic tools with motor assays that use highspeed cameras, muscle recordings (Mayer and Akay, 2018), and machine learning (Wiltschko et al., 2015; Nath et al., 2019) will enable a deeper understanding of how specific spinal cord touch networks are wired to shape movement, and how sensory information sculpts the recovery process after injury.

Using these tools, ongoing work by Abraira, Goulding, and colleagues have begun to identify touch-specific premotor networks important for sensorimotor function and recovery from injury. SCI studies in the cat and epidural stimulation protocols indicate the recruitment of cutaneous afferent pathways can facilitate locomotion. Interneurons interposed in these cutaneous pathways contribute to corrective motor behaviors (Rossignol et al., 2006; Bourane et al., 2015; Abraira et al., 2017; Paixão et al., 2019; Gatto et al., 2020), in part via networks in the intermediate spinal cord that integrate touch and proprioceptive information to influence specific patterns of muscle groups that facilitate both corrective movements during locomotion and motor "switching" during naturalistic behaviors (Fig. 2). Current work looking at the role of spinal cord intermediate zone interneurons in facilitating recovery from injury points to this spinal cord region as a critical therapeutic locus for SCI research. Although most current studies focus on sensory modalities in isolation, because the process of motor control and recovery encompasses several sensory modalities, the long-term goal of this type of work is to understand how spinal cord circuits process multimodal sensory information to shape movement. This will lay a foundation for novel ways of thinking about improving motor function after injury or disease.

\section{Cervical interneurons: critical role in movement control from supraspinal regions}

Approaches for restoring motor function after SCI have focused on either coaxing cortical and subcortical axons across the lesion to their synaptic partners (Raineteau and Schwab, 2001; Courtine et al., 2008), or activating cortical neurons using stimulation protocols to reestablish motor commands to spinal motor circuits below the lesion, either via rewiring or strengthening of spared connections. Within the field of SCI, it has long been appreciated that SpINs may contribute to the plasticity and functional improvement following injury, either via the formation of novel neuronal pathways (e.g., "bypass" pathways) or synapse remodeling (e.g., strengthening of existing pathways) (Stelzner, 2008; Zholudeva et al., 2018a) (Fig. 3). Work by Bareyre et al. (2004) was among the first to anatomically demonstrate this, showing that, after a partial thoracic SCI, cervical interneurons relayed supraspinal input to otherwise denervated lumbar locomotor networks. Subsequent studies by the Edgerton group showed that interneurons not only contributed spontaneously to plasticity after injury, but they could also be therapeutically harnessed to improve outcome after partial SCI. This was also more recently shown within respiratory networks (Darlot et al., 2012), where chemogenetic (Satkunendrarajah et al., 2018) or neurochemical (Streeter et al., 2020) stimulation of SpINs can modulate and even improve functional output after SCI. Engineering and transplantation of subsets of SpINs have also been shown to enhance plasticity and functional recovery after SCI (White et al., 2010; Brock et al., 2018; Dulin et al., 2018; Kumamaru et al., 2018; Zholudeva et al., 2018b). Notably, excitatory interneuron subtypes, particularly V2a SpINs, have been shown to be crucial for anatomic and functional plasticity (Satkunendrarajah et al., 2018) of respiratory function (Zholudeva et al., 2017).

Current strategies to restore walking after SCI stem from the classical view that locomotion is a simple behavior, consisting of rhythmic alternation of flexor and extensor motor pools on the left and right sides of the body. The basic rhythm and walking pattern are generated by a spinal neural network known as the locomotor central pattern generator (CPG) (Kiehn, 2006, 2016). While the component neurons of the locomotor CPG are distributed across numerous spinal cord segments, the SpINs with the greatest rhythmogenic potential are harbored in the ventral (laminae VII, VIII, X) lower thoracic, and upper lumbar spinal cord (Kjaerulff and Kiehn, 1996). To execute purposeful locomotion, however, activity in the locomotor CPG must be initiated based on internal goals and then modulated based on environmental signals. Therefore, the production of locomotion requires supraspinal and sensory inputs originating outside the spinal cord (Steeves and Jordan, 1980; Shefchyk et al., 1984; Garcia-Rill and Skinner, 1987; Drew, 1993; Matsuyama et al., 2004; Hagglund et al., 2010; Jankowska et al., 2011; Bouvier et al., 2015).

In mammals, lesion and stimulation studies have demonstrated that the motor cortex is the main area responsible for volitional movement control (Choi and Bastian, 2007; Rossignol et al., 2007; Grillner et al., 2008). However, to navigate the complex environment in which we live, the spinal cord's locomotor 
neural network relies heavily on feedback control from sensory fibers and feedforward control from higher centers, such as the visual cortex (Rossignol et al., 2006; Grillner et al., 2008; Drew and Marigold, 2015). A recent study demonstrated that the primary somatosensory cortex (SI), which receives and integrates information about the ever-changing internal and external environment, governs voluntary walking (Karadimas et al., 2020). Electrophysiological evidence suggests that a portion of the neural activity generated in SI before and during movement is a motor signal (Karadimas et al., 2020). Anatomical and electrophysiological investigations demonstrated that this SI motor signal bypasses the motor cortex and other brain or brainstem locomotor areas and modulates the lumbar locomotor CPG (L1L2) via cervical excitatory interneurons (C4-C5) (SI locomotor pathway). Furthermore, chemogenetic stimulation of this lumbar-projecting cervical pathway leads to enhanced locomotor speed, whereas chemogenetic silencing impairs ongoing locomotion and speed. However, numerous questions remain about the functional significance of the cervical SpINs that integrate descending cortical and bulbar signals to modulate spinal locomotor networks.

A critical challenge is to unravel how SpIN networks integrate descending inputs and sensory feedback to program locomotion. Long descending propriospinal neurons within the cervical spinal cord are ideally situated to integrate descending and ascending commands and to play key roles in speed, directionality, and postural stability of movement (Ruder et al., 2016). Lumbarprojecting cervical interneurons and lumbar SpINs play a key role in postural balance and forelimb and hindlimb coordination during high-speed treadmill locomotion (Ruder et al., 2016). These lumbar-projecting cervical neurons are mainly excitatory with unique developmental origin and projection patterns. Moreover, neurotransmitter-specific monosynaptic retrograde tracing experiments demonstrated that SI pyramidal neurons' efferent connectivity to the lumbar locomotor region is via cervical excitatory interneurons. These long descending cervical interneurons receive synaptic inputs from many cortical and bulbar regions involved in the regulation of locomotion, and thus provide a neuronal substrate for integrating and disseminating supraspinal information throughout the spinal circuitry to produce locomotion. Further knowledge of SpIN networks' function during mammalian locomotion will facilitate delineation of the neural mechanisms of locomotion and the development of novel targeted treatment strategies to restore walking in SCI patients.

\section{Synaptic silencing of SpINs reveals context-dependent locomotor hierarchies}

Work by McCrea et al. has investigated a phenomenon, known as "deletions," which was well known from studies of fictive locomotion in the decerebrate cat preparation (Lafreniere-Roula and McCrea, 2005). During these functional deletions, which occur when anatomic networks remain intact, the bursting activity of motoneurons decreases and disappears for a step or two within an otherwise robust period of fictive locomotion coordinated by the locomotor CPG. Importantly, when the deletions occur, the underlying rhythm of the fictive stepping does not change.

A collaborative effort between the McCrea and Rybak research teams to determine how and why deletions occur revealed that that the amplitude of motoneuron output during fictive locomotion is functionally independent of the locomotor rhythm (timing). This suggests that locomotor circuitry controlling each limb is arranged in levels with a functional hierarchy (Rybak et al., 2006; McCrea and Rybak, 2007). Over the past 15 years, this concept has led to the suggestion that the mammalian locomotor circuitry is arranged with a top "rhythmogenic module," or rhythm generator, responsible for the timing or tempo of movements, overlying a pattern formation network, that is responsible for intralimb (hip, knee, and ankle) coordination (Rybak et al., 2006, 2015; McCrea and Rybak, 2008). Specifically, the most recent computer models contain a "half-center" rhythm generator consisting of reciprocally coupled flexor and extensor related excitatory interneurons controlling each limb, with a pattern formation layer controlling motor synergies and the output of muscle activity patterns within the limb. Interlimb coordination is determined by networks of local commissural interneurons and long ascending and descending propriospinal neurons that interconnect the circuits in each quadrant (Rybak et al., 2015; Danner et al., 2017). Interlimb coordination has been attributed to SpINs derived from V-class progenitor cells in the mouse; but, as discussed earlier, their contributions to the rhythm generator and pattern formation circuits remain poorly understood.

A recent set of experiments by Magnuson et al. began to explore the contribution of SpINs within the proposed sites of rhythm generation, and the long ascending and descending proprio-SpINs that integrate cervical and lumbar networks, to locomotion. Using excitotoxic (Magnuson et al., 1999; Hadi et al., 2000) and contusive (Magnuson et al., 2005) spinal cord injuries revealed that the greatest impact on locomotor function occurs when the L2 spinal segment is targeted, rather than the L3/4 or T9/10 levels. This result supports the notion that the rhythm generator circuitry is centered in the upper lumbar cord. Accordingly, the Magnuson team began exploring the roles of SpINs with cell bodies at L2 using a two-virus synaptic silencing system (Kinoshita et al., 2012). These experiments revealed that, of the L2 neurons that project to L5, 50:50 were ipsilateral and contralateral, and most were excitatory. Based on the simple concept that L2 motor output is more flexor-related while L5 output is more extensor-related, the researchers hypothesized that silencing these neurons would disrupt intralimb (flexor-extensor) coordination. However, when L2-L5 interneurons were silenced, the right and left hindlimbs were partially decoupled, and could adopt any right-left phase from pure alternation to synchrony (hopping) at speeds normally associated with pure alternation. None of the other fundamental characteristics of locomotion were disrupted (Pocratsky et al., 2017). This, together with other functional studies targeting ventral interneurons (Lanuza et al., 2004; Y. Zhang et al., 2008; Talpalar et al., 2013; J. Zhang et al., 2014), demonstrates that, for the hindlimbs at least, interlimb coordination circuits can be functionally separated from rhythm generation and intralimb pattern formation. Ongoing research, some described below, is focused on further elucidating the specific roles of SpINs in rhythm generation, interlimb coordination, and pattern formation.

Subsequent studies focused on long propriospinal neurons that interconnect the two hindlimb quadrants (containing rhythm generators for each hindlimb) to the forelimb circuitry with rhythm generators for both forelimbs. Specific attention was given to a subpopulation of long-ascending proprio-SpINs with cell bodies residing in the intermediate gray matter at lumbar segments (L1-L3), and with projections to the intermediate gray matter at $\mathrm{C6}-\mathrm{C} 7$, regions essential for locomotor pattern 
generation for the hindlimbs and forelimbs, respectively. This population is composed of $\sim 50: 50$ ipsilaterally and contralaterally projecting interneurons, with decussating axons that cross at or near the level of the cell bodies. Given their role in interenlargement (lumbar to cervical) connectivity, the expectation was that silencing long-ascending propriospinal neurons would lead to disruption in hindlimb-forelimb coordination. Instead, overt disruptions in right-left coordination were observed in both forelimbs and hindlimbs. In addition, each limb pair, normally coupled strongly to maintain strict alternation at walking and trotting speeds, was partially decoupled. This disruption affected both limb girdles equally (approximately the same proportion of disrupted steps), despite the fact that only ascending information was silenced (L2 to C6). These disruptions were independent of walking speed, and surprisingly, did not alter intralimb (flexor-extensor) coordination. Hindlimb-forelimb coordination was only modestly influenced, and at no time was the 1:1 ratio of limb involvement in stepping disrupted. These disruptions in interlimb coordination were also seen to be context-dependent, and occurred only when the animals were walking from point $\mathrm{A}$ to $\mathrm{B}$, nose-up (nonexploratory) on a surface with good grip. They did not occur on a treadmill, when the animals were exploring (nose-down) or when the animals were walking on a slick surface (Pocratsky et al., 2020). A further point of interest is that silencing these long-ascending propriospinal neurons had no influence on another locomotor activity, swimming. In rats, swimming is a bipedal activity where only the hindlimbs are used for propulsion. Animals retained strict hindlimb alternation during swimming when the long-ascending propriospinal neurons were silenced arguing that sensory input modulates or gates the roles played by these interneurons during different modes of locomotion (Pocratsky et al., 2020).

These observations support the concept that there are quasiindependent modules comprised of commissural interneurons, long-ascending and descending propriospinal neurons that mediate the coordination of each pair of limbs, and that the balance of their activity defines the locomotor gait, allowing for great flexibility in interlimb coordination while preserving stability (Danner et al., 2016, 2017).

In addition, the results lead to speculation that there exists a dynamic relationship between spinal autonomy and supraspinal oversight. When walking on a smooth surface with good grip, silencing long-ascending proprio-SpINs results in partial decoupling of the right and left limbs at each girdle by reducing the efficacy of the right-left phase module. However, when stepping on the treadmill, on a slick surface, or during exploratory, nosedown locomotion, supra-spinal oversight ensures the functional stability of right-left alternation at each girdle. Thus, it could be that there is a state-dependent hierarchy where right-left phase control of both limb pairs is driven by lumbar circuitry in some contexts and is supraspinally secured in others (Pocratsky et al., $2017,2020)$. While the interconnectivity between long proprioSpINs has been explored for many years (Giovanelli and Crotti, 1972; English et al., 1985; Rybak et al., 2015), demonstration of the functional consequences of disconnection between cervical and lumbar populations offers a unique insight into flexibility and how locomotion can persist after SCI, albeit with altered kinematics.

\section{Therapeutically targeting SpINs}

As highlighted here, SpINs play diverse roles in shaping motor and sensory information. What these roles are normally, and how they might change following traumatic SCI, becomes important in understanding postinjury function (adaptive or maladaptive plasticity). Indeed, SpINs are now recognized as a key component of plasticity and function post-SCI, by contributing to neural circuit remodeling and modulation of motoneuron excitability (Stelzner and Cullen, 1991; Bareyre et al., 2004; Courtine et al., 2008; Harkema, 2008; Lane et al., 2008, 2009; Sandhu et al., 2009; Alilain et al., 2011; Flynn et al., 2011; Zholudeva et al., 2017). With a growing appreciation of the neuroplastic potential of the injured spinal cord, and of the contribution of SpINs to this plasticity (Takeoka et al., 2014; Zholudeva et al., 2017; Satkunendrarajah et al., 2018; Jensen et al., 2019a), has come a greater focus on how plasticity can be therapeutically enhanced.

\section{Exciting spinal networks to promote recovery: targeting} glutamatergic SpINs

Two key areas of development of therapeutics that enhance plasticity and recovery following incomplete SCI are as follows: (1) activity-based therapies and rehabilitative approaches and (2) neural interfacing to activate neural networks with exogenous stimuli (for review, see Houle and Côté, 2013; Behrman et al., 2017; Hormigo et al., 2017). With the use of intraspinal electrophysiology, advanced neuroanatomical methods (viral tracing, immunohistochemistry) and/or genetic sequencing, the contribution of SpINs to plasticity has become more evident in preclinical models of SCI (Skup et al., 2012; van den Brand et al., 2012; Gajewska-Woźniak et al., 2016; Streeter et al., 2017; Skinnider et al., 2020). Although defining similar roles for SpINs within the injured human spinal cord has been more challenging, there is some evidence to support their role in patient recovery.

With increasing clinical use of operative neuromodulation and translational interest in electrical stimulation (e.g., functional electrical stimulation) (Johnston et al., 2005; Dimarco and Kowalski, 2013; DiMarco and Kowalski, 2019; Bourbeau et al., 2020), transmagnetic stimulation (Hou et al., 2020), epidural stimulation (Edgerton and Harkema, 2011; Sayenko et al., 2014), and intraspinal stimulation (Kasten et al., 2013; Mondello et al., 2014; Mercier et al., 2017; Toossi et al., 2017), there has been increased effort to identify the contribution that SpINs make to functional outcomes. While the substrates affected by stimulation have remained elusive, several studies have now confirmed that SpINs are activated by epidural (van den Brand et al., 2012; Skinnider et al., 2020) and intraspinal stimulation (Mushahwar et al., 2004; Sunshine et al., 2018). Similarly, histologic analyses of SpINs following activity-based therapies has shown that they increase their activity with treatment (Houle and Côté, 2013; Streeter et al., 2017). The phenotype of interneurons targeted by each treatment strategy, however, and whether different treatments might target different subpopulations, remains unclear.

Another more recent advance in therapeutics that harness SpINs has been the use of cellular engineering to create populations of specific interneuronal subtypes for transplantation. While transplantation of neural precursor cells has long been shown to improve outcomes following SCI (Fischer et al., 2020), recent attention has been given to the origin of neuronal progenitors and the SpIN component of these transplantable cells (White et al., 2010; Dulin et al., 2018). As developmental biology has provided markers for identifying subsets of SpINs, research has begun to tailor donor cell populations to contain therapeutically appropriate subpopulations (e.g., engineering SpINs for transplantation that are known to contribute to plasticity and recovery) (Iyer et al., 2017; Butts et al., 2019). For instance, the delivery after cervical SCI of excitatory V2a premotor interneurons, 
which are known to contribute to respiratory plasticity (Romer et al., 2016; Zholudeva et al., 2017; Satkunendrarajah et al., 2018; Jensen et al., 2019a), enhances the degree of respiratory recovery (Zholudeva et al., 2018b). These more refined and tailored transplants will likely improve on prior transplantation methods, providing greater and more consistent functional recovery. It is hoped that, as we learn which subtypes of interneurons are involved in adaptive and/or maladaptive plasticity, more appropriately targeted therapies can be developed.

\section{To inhibit or disinhibit: targeting the complex roles of inhibitory} SpINs

While there has been mounting interest in the contribution of excitatory SpINs to the restoration of motor function, an essential consideration is that excessive excitation could exacerbate maladaptive plasticity, thus, for example, increasing pain, spasticity, or dysreflexia. These functional deficits, which are generally considered to be a result of overexcitation, can be attenuated by suppressing overexcitation directly (with glutamatergic antagonists) or indirectly (by targeting inhibitory networks, e.g., with GABA agonists or analogs). As shown with transplantation of excitatory neuronal progenitors, delivery of inhibitory interneurons may also provide a means for attenuating dysfunctional overexcitability in spinal networks (Jergova et al., 2012; Fandel et al., 2016).

Although treating pain and spasticity may require attenuation of excitatory neurons and/or inhibition of overactive excitatory networks, excessive inhibition is also deleterious for recovery of motor function (Chen et al., 2018). Indeed, silencing inhibitory SpINs has been shown to (re)activate dormant/latent spinal pathways, thus amplifying restorative plasticity and recovery. This disinhibition or "unsilencing" of spinal networks by targeting inhibitory SpINs has been achieved by targeting neurotransmitter receptors pharmacologically. Local delivery of GABAergic or glycinergic antagonists can even enhance the efficacy of other treatments (Bezdudnaya et al., 2020). Perhaps more selective approaches, such as the delivery of a KCC2 agonist, as described by Chen et al. (2018), will allow efficacious yet targeted treatment. As our understanding of the specific populations involved in premotor inhibitory spinal networks improves, treatments can be developed to better target those neurons selectively.

In conclusion, there is a growing effort to identify SpINs that contribute to motor, sensory, and autonomic functions. Research in developmental neurobiology and spinal cord biology, neurotrauma, and disease is revealing a highly diverse population of neurons that not only shape many neural functions, but also act as gatekeepers to many restorative and maladaptive forms of plasticity. Collaborative efforts among multidisciplinary teams are providing a wealth of information, and the identity of specific interneurons associated with spontaneous or therapeutically driven plasticity can now be more effectively assessed. As ongoing work continues to identify SpIN subtypes and improve our understanding of their contribution to function following injury, treatments can be tailored to minimize maladaptive consequences and better harness their restorative neuroplastic potential.

\section{References}

Abraira VE, Ginty DD (2013) The sensory neurons of touch. Neuron 79:618-639.

Abraira VE, Kuehn ED, Chirila AM, Springel MW, Toliver AA, Zimmerman AL, Orefice LL, Boyle KA, Bai L, Song BJ, Bashista KA, O’Neill TG, Zhuo J, Tsan C, Hoynoski J, Rutlin M, Kus L, Niederkofler V, Watanabe M,
Dymecki SM, et al. (2017) The cellular and synaptic architecture of the mechanosensory dorsal horn. Cell 168:295-310.e219.

Akay T, Tourtellotte WG, Arber S, Jessell TM (2014) Degradation of mouse locomotor pattern in the absence of proprioceptive sensory feedback. Proc Natl Acad Sci USA 111:16877-16882.

Alaynick WA, Jessell TM, Pfaff SL (2011) SnapShot: spinal cord development. Cell 146:178.e1.

Alilain WJ, Horn KP, Hu H, Dick TE, Silver J (2011) Functional regeneration of respiratory pathways after spinal cord injury. Nature 475:196-200.

Alvarez FJ, Jonas PC, Sapir T, Hartley R, Berrocal MC, Geiman EJ, Todd AJ, Goulding M (2005) Postnatal phenotype and localization of spinal cord V1 derived interneurons. J Comp Neurol 493:177-192.

Bareyre FM, Kerschensteiner M, Raineteau O, Mettenleiter TC, Weinmann O, Schwab ME (2004) The injured spinal cord spontaneously forms a new intraspinal circuit in adult rats. Nat Neurosci 7:269-277.

Behrman AL, Ardolino EM, Harkema SJ (2017) Activity-based therapy: from basic science to clinical application for recovery after spinal cord injury. J Neurol Phys Ther 41 Suppl 3:S39-S45.

Bezdudnaya T, Lane MA, Marchenko V (2020) Pharmacological disinhibition enhances paced breathing following complete spinal cord injury in rats. Respir Physiol Neurobiol 282:103514.

Bikoff JB, Gabitto MI, Rivard AF, Drobac E, Machado TA, Miri A, BrennerMorton S, Famojure E, Diaz C, Alvarez FJ, Mentis GZ, Jessell TM (2016) Spinal inhibitory interneuron diversity delineates variant motor microcircuits. Cell 165:207-219.

Bourane S, Grossmann KS, Britz O, Dalet A, Del Barrio MG, Stam FJ, Garcia-Campmany L, Koch S, Goulding M (2015) Identification of a spinal circuit for light touch and fine motor control. Cell 160:503-515.

Bourbeau D, Bolon A, Creasey G, Dai W, Fertig B, French J, Jeji T, Kaiser A, Kouznetsov R, Rabchevsky A, Santacruz BG, Sun J, Thor KB, Wheeler T, Wierbicky J (2020) Needs, priorities, and attitudes of individuals with spinal cord injury toward nerve stimulation devices for bladder and bowel function: a survey. Spinal Cord 58:1216-1226.

Bouvier J, Caggiano V, Leiras R, Caldeira V, Bellardita C, Balueva K, Fuchs A, Kiehn O (2015) Descending command neurons in the brainstem that halt locomotion. Cell 163:1191-1203.

Britz O, Zhang J, Grossmann KS, Dyck J, Kim JC, Dymecki S, Gosgnach S, Goulding M (2015) A genetically defined asymmetry underlies the inhibitory control of flexor-extensor locomotor movements. Elife 4:e04718.

Brock JH, Graham L, Staufenberg E, Im S, Tuszynski MH (2018) Rodent neural progenitor cells support functional recovery after cervical spinal cord contusion. J Neurotrauma 35:1069-1078.

Brownstone RM, Wilson JM (2008) Strategies for delineating spinal locomotor rhythm-generating networks and the possible role of $\mathrm{Hb} 9$ interneurones in rhythmogenesis. Brain Res Rev 57:64-76.

Bui TV, Brownstone RM (2015) Sensory-evoked perturbations of locomotor activity by sparse sensory input: a computational study. J Neurophysiol 113:2824-2839.

Bui TV, Stifani N, Panek I, Farah C (2015) Genetically identified spinal interneurons integrating tactile afferents for motor control. J Neurophysiol 114:3050-3063.

Burke RE (2007) Sir Charles Sherrington's the integrative action of the nervous system: a centenary appreciation. Brain 130:887-894.

Butts JC, Iyer N, White N, Thompson R, Sakiyama-Elbert S, McDevitt TC (2019) V2a interneuron differentiation from mouse and human pluripotent stem cells. Nat Protoc 14:3033-3058.

Caldeira V, Dougherty KJ, Borgius L, Kiehn O (2017) Spinal Hb9::Crederived excitatory interneurons contribute to rhythm generation in the mouse. Sci Rep 7:41369.

Callahan RA, Roberts R, Sengupta M, Kimura Y, Higashijima SI, Bagnall MW (2019) Spinal V2b neurons reveal a role for ipsilateral inhibition in speed control. Elife 8:e47837.

Chen B, Li Y, Yu B, Zhang Z, Brommer B, Williams PR, Liu Y, Hegarty SV, Zhou S, Zhu J, Guo H, Lu Y, Zhang Y, Gu X, He Z (2018) Reactivation of dormant relay pathways in injured spinal cord by KCC2 manipulations. Cell 174:1599.

Choi JT, Bastian AJ (2007) Adaptation reveals independent control networks for human walking. Nat Neurosci 10:1055-1062.

Courtine G, Song B, Roy RR, Zhong H, Herrmann JE, Ao Y, Qi J, Edgerton VR, Sofroniew MV (2008) Recovery of supraspinal control of stepping via indirect propriospinal relay connections after spinal cord injury. Nat Med 14:69-74. 
Danner SM, Wilshin SD, Shevtsova NA, Rybak IA (2016) Central control of interlimb coordination and speed-dependent gait expression in quadrupeds. J Physiol 594:6947-6967.

Danner SM, Shevtsova NA, Frigon A, Rybak IA (2017) Computational modeling of spinal circuits controlling limb coordination and gaits in quadrupeds. Elife 6:e31050.

Darlot F, Cayetanot F, Gauthier P, Matarazzo V, Kastner A (2012) Extensive respiratory plasticity after cervical spinal cord injury in rats: axonal sprouting and rerouting of ventrolateral bulbospinal pathways. Exp Neurol 236:88-102.

Delile J, Rayon T, Melchionda M, Edwards A, Briscoe J, Sagner A (2019) Single cell transcriptomics reveals spatial and temporal dynamics of gene expression in the developing mouse spinal cord. Development 146: $\operatorname{dev} 173807$.

Dimarco AF, Kowalski KE (2013) Spinal pathways mediating phrenic activation during high frequency spinal cord stimulation. Respir Physiol Neurobiol 186:1-6.

DiMarco AF, Kowalski KE (2019) High-frequency spinal cord stimulation in a subacute animal model of spinal cord injury. J Appl Physiol 127:98102

Dobrott CI, Sathyamurthy A, Levine AJ (2019) Decoding cell type diversity within the spinal cord. Curr Opin Physiol 8:1-6.

Dougherty KJ, Kiehn O (2010a) Firing and cellular properties of V2a interneurons in the rodent spinal cord. J Neurosci 30:24-37.

Dougherty KJ, Kiehn O (2010b) Functional organization of V2a-related locomotor circuits in the rodent spinal cord. Ann NY Acad Sci 1198:85-93.

Dougherty KJ, Zagoraiou L, Satoh D, Rozani I, Doobar S, Arber S, Jessell TM, Kiehn O (2013) Locomotor rhythm generation linked to the output of spinal shox2 excitatory interneurons. Neuron 80:920-933.

Drew T (1993) Motor cortical activity during voluntary gait modifications in the cat: I. Cells related to the forelimbs. J Neurophysiol 70:179-199.

Drew T, Marigold DS (2015) Taking the next step: cortical contributions to the control of locomotion. Curr Opin Neurobiol 33:25-33.

Dulin JN, Adler AF, Kumamaru H, Poplawski GH, Lee-Kubli C, Strobl H, Gibbs D, Kadoya K, Fawcett JW, Lu P, Tuszynski MH (2018) Injured adult motor and sensory axons regenerate into appropriate organotypic domains of neural progenitor grafts. Nat Commun 9:84.

Edgerton VR, Harkema S (2011) Epidural stimulation of the spinal cord in spinal cord injury: current status and future challenges. Expert Rev Neurother 11:1351-1353.

English AW, Tigges J, Lennard PR (1985) Anatomical organization of long ascending propriospinal neurons in the cat spinal cord. J Comp Neurol 240:349-358.

Fandel TM, Trivedi A, Nicholas CR, Zhang H, Chen J, Martinez AF, NobleHaeusslein LJ, Kriegstein AR (2016) Transplanted human stem cellderived interneuron precursors mitigate mouse bladder dysfunction and central neuropathic pain after spinal cord injury. Cell Stem Cell 19:544557.

Fischer I, Dulin JN, Lane MA (2020) Transplanting neural progenitor cells to restore connectivity after spinal cord injury. Nat Rev Neurosci 21:366383.

Flynn JR, Graham BA, Galea MP, Callister RJ (2011) The role of propriospinal interneurons in recovery from spinal cord injury. Neuropharmacology 60:809-822.

Flynn JR, Conn VL, Boyle KA, Hughes DI, Watanabe M, Velasquez T, Goulding MD, Callister RJ, Graham BA (2017) Anatomical and molecular properties of long descending propriospinal neurons in mice. Front Neuroanat 11:5

Gabitto MI, Pakman A, Bikoff JB, Abbott LF, Jessell TM, Paninski L (2016) Bayesian sparse regression analysis documents the diversity of spinal inhibitory interneurons. Cell 165:220-233.

Gajewska-Woźniak O, Grycz K, Czarkowska-Bauch J, Skup M (2016) Electrical stimulation of low-threshold proprioceptive fibers in the adult rat increases density of glutamatergic and cholinergic terminals on ankle extensor alpha-motoneurons. PLoS One 11:e0161614.

Garcia-Rill E, Skinner RD (1987) The mesencephalic locomotor region: I. Activation of a medullary projection site. Brain Res 411:1-12.

Gatto G, Bourane S, Ren X, Di Costanzo S, Fenton PK, Halder P, Seal RP, Goulding MD (2020) A functional topographic map for spinal sensorimotor reflexes. Neuron Advance online publication. Retrieved November 4, 2020. doi: 10.1016/j.neuron.2020.10.003.
Giovanelli M, Crotti F (1972) Anatomical and functional organization of the ascending long propriospinal pathways in the cat. Acta Neurol (Napoli) $27: 220-224$

Gosgnach S, Lanuza GM, Butt SJ, Saueressig H, Zhang Y, Velasquez T, Riethmacher D, Callaway EM, Kiehn O, Goulding M (2006) V1 spinal neurons regulate the speed of vertebrate locomotor outputs. Nature 440:215-219.

Goulding M (2009) Circuits controlling vertebrate locomotion: moving in a new direction. Nat Rev Neurosci 10:507-518.

Grillner S, Rossignol S (1978) On the initiation of the swing phase of locomotion in chronic spinal cats. Brain Res 146:269-277.

Grillner S, Wallen P, Saitoh K, Kozlov A, Robertson B (2008) Neural bases of goal-directed locomotion in vertebrates: an overview. Brain Res Rev 57:2-12.

Hadi B, Zhang YP, Burke DA, Shields CB, Magnuson DS (2000) Lasting paraplegia caused by loss of lumbar spinal cord interneurons in rats: no direct correlation with motor neuron loss. J Neurosurg 93:266-275.

Hagglund M, Borgius L, Dougherty KJ, Kiehn O (2010) Activation of groups of excitatory neurons in the mammalian spinal cord or hindbrain evokes locomotion. Nat Neurosci 13:246-252.

Haring M, Zeisel A, Hochgerner H, Rinwa P, Jakobsson JE, Lonnerberg P, La Manno G, Sharma N, Borgius L, Kiehn O, Lagerstrom MC, Linnarsson S, Ernfors P (2018) Neuronal atlas of the dorsal horn defines its architecture and links sensory input to transcriptional cell types. Nat Neurosci 21:869-880.

Harkema SJ (2008) Plasticity of interneuronal networks of the functionally isolated human spinal cord. Brain Res Rev 57:255-264.

Hayashi M, Hinckley CA, Driscoll SP, Moore NJ, Levine AJ, Hilde KL, Sharma K, Pfaff SL (2018) Graded arrays of spinal and supraspinal V2a interneuron subtypes underlie forelimb and hindlimb motor control. Neuron 97:869-884.e865.

Hiebert GW, Whelan PJ, Prochazka A, Pearson KG (1996) Contribution of hind limb flexor muscle afferents to the timing of phase transitions in the cat step cycle. J Neurophysiol 75:1126-1137.

Hormigo KM, Zholudeva LV, Spruance VM, Marchenko V, Côté MP, Vinit S, Giszter S, Bezdudnaya T, Lane MA (2017) Enhancing neural activity to drive respiratory plasticity following cervical spinal cord injury. Exp Neurol 287:276-287.

Hou J, Nelson R, Mohammad N, Mustafa G, Plant D, Thompson FJ, Bose P (2020) Effect of simultaneous combined treadmill training and magnetic stimulation on spasticity and gait impairments after cervical spinal cord injury. J Neurotrauma 37:1999-2013.

Houle JD, Côté MP (2013) Axon regeneration and exercise-dependent plasticity after spinal cord injury. Ann NY Acad Sci 1279:154-163.

Iyer NR, Wilems TS, Sakiyama-Elbert SE (2017) Stem cells for spinal cord injury: strategies to inform differentiation and transplantation. Biotechnol Bioeng 114:245-259.

Jankowska E, Nilsson E, Hammar I (2011) Processing information related to centrally initiated locomotor and voluntary movements by feline spinocerebellar neurones. J Physiol 589:5709-5725.

Jensen VN, Alilain WJ, Crone SA (2019a) Role of propriospinal neurons in control of respiratory muscles and recovery of breathing following injury. Front Syst Neurosci 13:84.

Jensen VN, Seedle K, Turner SM, Lorenz JN, Crone SA (2019b) V2a neurons constrain extradiaphragmatic respiratory muscle activity at rest. eNeuro 6:ENEURO.0492-18.2019.

Jergova S, Hentall ID, Gajavelli S, Varghese MS, Sagen J (2012) Intraspinal transplantation of GABAergic neural progenitors attenuates neuropathic pain in rats: a pharmacologic and neurophysiological evaluation. Exp Neurol 234:39-49.

Johnston TE, Betz RR, Smith BT, Benda BJ, Mulcahey MJ, Davis R, Houdayer TP, Pontari MA, Barriskill A, Creasey GH (2005) Implantable FES system for upright mobility and bladder and bowel function for individuals with spinal cord injury. Spinal Cord 43:713-723.

Karadimas SK, Satkunendrarajah K, Laliberte AM, Ringuette D, Weisspapir I, Li L, Gosgnach S, Fehlings MG (2020) Sensory cortical control of movement. Nat Neurosci 23:75-84.

Kasten MR, Sunshine MD, Secrist ES, Horner PJ, Moritz CT (2013) Therapeutic intraspinal microstimulation improves forelimb function after cervical contusion injury. J Neural Eng 10:044001.

Kiehn O (2006) Locomotor circuits in the mammalian spinal cord. Annu Rev Neurosci 29:279-306. 
Kiehn O (2016) Decoding the organization of spinal circuits that control locomotion. Nat Rev Neurosci 17:224-238.

Kinoshita M, Matsui R, Kato S, Hasegawa T, Kasahara H, Isa K, Watakabe A, Yamamori T, Nishimura Y, Alstermark B, Watanabe D, Kobayashi K, Isa $\mathrm{T}$ (2012) Genetic dissection of the circuit for hand dexterity in primates. Nature 487:235-238.

Kjaerulff O, Kiehn O (1996) Distribution of networks generating and coordinating locomotor activity in the neonatal rat spinal cord in vitro: a lesion study. J Neurosci 16:5777-5794.

Konsolaki E, Koropouli E, Tsape E, Pothakos K, Zagoraiou L (2020) Genetic inactivation of cholinergic $\mathrm{C}$ bouton output improves motor performance but not survival in a mouse model of amyotrophic lateral sclerosis. Neuroscience 450:71-80.

Kumamaru H, Kadoya K, Adler AF, Takashima Y, Graham L, Coppola G, Tuszynski MH (2018) Generation and post-injury integration of human spinal cord neural stem cells. Nat Methods 15:723-731.

Lafreniere-Roula M, McCrea DA (2005) Deletions of rhythmic motoneuron activity during fictive locomotion and scratch provide clues to the organization of the mammalian central pattern generator. J Neurophysiol 94:1120-1132.

Lai HC, Seal RP, Johnson JE (2016) Making sense out of spinal cord somatosensory development. Development 143:3434-3448.

Lam T, Pearson KG (2001) Proprioceptive modulation of hip flexor activity during the swing phase of locomotion in decerebrate cats. J Neurophysiol 86:1321-1332.

Lane MA, Lee KZ, Fuller DD, Reier PJ (2009) Spinal circuitry and respiratory recovery following spinal cord injury. Respir Physiol Neurobiol 169:123-132.

Lane MA, White TE, Coutts MA, Jones AL, Sandhu MS, Bloom DC, Bolser DC, Yates BJ, Fuller DD, Reier PJ (2008) Cervical prephrenic interneurons in the normal and lesioned spinal cord of the adult rat. J Comp Neurol 511:692-709.

Lanuza GM, Gosgnach S, Pierani A, Jessell TM, Goulding M (2004) Genetic identification of spinal interneurons that coordinate left-right locomotor activity necessary for walking movements. Neuron 42:375-386.

Li L, Rutlin M, Abraira VE, Cassidy C, Kus L, Gong S, Jankowski MP, Luo W, Heintz N, Koerber HR, Woodbury CJ, Ginty DD (2011) The functional organization of cutaneous low-threshold mechanosensory neurons. Cell 147:1615-1627.

Lloyd DP (1942) Mediation of descending long spinal reflex activity. J Neurophysiol 5:435-458.

Lloyd DP, McIntyre AK (1948) Analysis of forelimb-hindlimb reflex activity in acutely decapitate cats. J Neurophysiol 11:455-470.

Lu DC, Niu T, Alaynick WA (2015) Molecular and cellular development of spinal cord locomotor circuitry. Front Mol Neurosci 8:25.

Magnuson DS, Trinder TC, Zhang YP, Burke D, Morassutti DJ, Shields CB (1999) Comparing deficits following excitotoxic and contusion injuries in the thoracic and lumbar spinal cord of the adult rat. Exp Neurol 156:191204.

Magnuson DS, Lovett R, Coffee C, Gray R, Han Y, Zhang YP, Burke DA (2005) Functional consequences of lumbar spinal cord contusion injuries in the adult rat. J Neurotrauma 22:529-543.

Matsuyama K, Mori F, Nakajima K, Drew T, Aoki M, Mori S (2004) Locomotor role of the corticoreticular-reticulospinal-spinal interneuronal system. Prog Brain Res 143:239-249.

Mayer WP, Akay T (2018) Stumbling corrective reaction elicited by mechani$\mathrm{cal}$ and electrical stimulation of the saphenous nerve in walking mice. J Exp Biol 221:jeb178095.

McCrea DA, Rybak IA (2007) Modeling the mammalian locomotor CPG: insights from mistakes and perturbations. Prog Brain Res 165:235-253.

McCrea DA, Rybak IA (2008) Organization of mammalian locomotor rhythm and pattern generation. Brain Res Rev 57:134-146.

Mercier LM, Gonzalez-Rothi EJ, Streeter KA, Posgai SS, Poirier AS, Fuller DD, Reier PJ, Baekey DM (2017) Intraspinal microstimulation and diaphragm activation after cervical spinal cord injury. J Neurophysiol 117:767-776.

Mondello SE, Kasten MR, Horner PJ, Moritz CT (2014) Therapeutic intraspinal stimulation to generate activity and promote long-term recovery. Front Neurosci 8:21.

Mushahwar VK, Aoyagi Y, Stein RB, Prochazka A (2004) Movements generated by intraspinal microstimulation in the intermediate gray matter of the anesthetized, decerebrate, and spinal cat. Can J Physiol Pharmacol $82: 702-714$
Nath T, Mathis A, Chen AC, Patel A, Bethge M, Mathis MW (2019) Using DeepLabCut for 3D markerless pose estimation across species and behaviors. Nat Protoc 14:2152-2176.

Paixão S, Loschek L, Gaitanos L, Alcalà Morales P, Goulding M, Klein R (2019) Identification of spinal neurons contributing to the dorsal column projection mediating fine touch and corrective motor movements. Neuron 104:749-764.e746.

Pearson KG, Rossignol S (1991) Fictive motor patterns in chronic spinal cats. J Neurophysiol 66:1874-1887.

Pocratsky AM, Burke DA, Morehouse JR, Beare JE, Riegler AS, Tsoulfas P, States GJ, Whittemore SR, Magnuson DS (2017) Reversible silencing of lumbar spinal interneurons unmasks a task-specific network for securing hindlimb alternation. Nat Commun 8:1963.

Pocratsky AM, Shepard CT, Morehouse JR, Burke DA, Riegler AS, Hardin JT, Beare JE, Hainline C, States GJ, Brown BL, Whittemore SR, Magnuson DS (2020) Long ascending propriospinal neurons provide flexible, context-specific control of interlimb coordination. Elife 9:e53565.

Raineteau O, Schwab ME (2001) Plasticity of motor systems after incomplete spinal cord injury. Nat Rev Neurosci 2:263-273.

Ramon y Cajal S, Swanson N, Swanson L (1995) Histology of the nervous system of man and vertebrates. Oxford: Oxford UP.

Rexed B (1952) The cytoarchitectonic organization of the spinal cord in the cat. J Comp Neurol 96:414-495.

Rexed B (1954) A cytoarchitectonic atlas of the spinal cord in the cat. J Comp Neurol 100:297-379.

Romer SH, Seedle K, Turner SM, Li J, Baccei ML, Crone SA (2016) Accessory respiratory muscles enhance ventilation in ALS model mice and are activated by excitatory V2a neurons. Exp Neurol 287:192-204.

Rosenberg AB, Roco CM, Muscat RA, Kuchina A, Sample P, Yao Z, Graybuck LT, Peeler DJ, Mukherjee S, Chen W, Pun SH, Sellers DL, Tasic B, Seelig G (2018) Single-cell profiling of the developing mouse brain and spinal cord with split-pool barcoding. Science 360:176-182.

Rossignol S, Dubuc R, Gossard JP (2006) Dynamic sensorimotor interactions in locomotion. Physiol Rev 86:89-154.

Rossignol S, Schwab M, Schwartz M, Fehlings MG (2007) Spinal cord injury: time to move? J Neurosci 27:11782-11792.

Rozani I, Tsapara G, Witts EC, Deaville SJ, Miles GB, Zagoraiou L (2019) Pitx2 cholinergic interneurons are the source of $\mathrm{C}$ bouton synapses on brainstem motor neurons. Sci Rep 9:4936.

Ruder L, Takeoka A, Arber S (2016) Long-distance descending spinal neurons ensure quadrupedal locomotor stability. Neuron 92:1063-1078.

Rutlin M, Ho CY, Abraira VE, Cassidy C, Bai L, Woodbury CJ, Ginty DD (2015) The cellular and molecular basis of direction selectivity of $\mathrm{A} \delta$ LTMRs. Cell 160:1027.

Rybak IA, Shevtsova NA, Lafreniere-Roula M, McCrea DA (2006) Modelling spinal circuitry involved in locomotor pattern generation: insights from deletions during fictive locomotion. J Physiol 577:617-639.

Rybak IA, Dougherty KJ, Shevtsova NA (2015) Organization of the mammalian locomotor CPG: review of computational model and circuit architectures based on genetically identified spinal interneurons $(1,2,3)$. eNeuro 2 : ENEURO.0069-15.2015.

Salamatina A, Yang JH, Brenner-Morton S, Bikoff JB, Fang L, Kintner CR, Jessell TM, Sweeney LB (2020) Differential loss of spinal interneurons in a mouse model of ALS. Neuroscience 450:81-95.

Sandhu MS, Dougherty BJ, Lane MA, Bolser DC, Kirkwood PA, Reier PJ, Fuller DD (2009) Respiratory recovery following high cervical hemisection. Respir Physiol Neurobiol 169:94-101.

Sapir T, Geiman EJ, Wang Z, Velasquez T, Mitsui S, Yoshihara Y, Frank E, Alvarez FJ, Goulding M (2004) Pax6 and engrailed 1 regulate two distinct aspects of Renshaw cell development. J Neurosci 24:1255-1264.

Sathyamurthy A, Johnson KR, Matson KJ, Dobrott CI, Li L, Ryba AR, Bergman TB, Kelly MC, Kelley MW, Levine AJ (2018) Massively parallel single nucleus transcriptional profiling defines spinal cord neurons and their activity during behavior. Cell Rep 22:2216-2225.

Satkunendrarajah K, Karadimas SK, Laliberte AM, Montandon G, Fehlings MG (2018) Cervical excitatory neurons sustain breathing after spinal cord injury. Nature 562:419-422.

Sayenko DG, Angeli C, Harkema SJ, Edgerton VR, Gerasimenko YP (2014) Neuromodulation of evoked muscle potentials induced by epidural spinal-cord stimulation in paralyzed individuals. J Neurophysiol 111:10881099 . 
Shefchyk SJ, Jell RM, Jordan LM (1984) Reversible cooling of the brainstem reveals areas required for mesencephalic locomotor region evoked treadmill locomotion. Exp Brain Res 56:257-262.

Sherrington CS, Laslett EE (1903a) Observations on some spinal reflexes and the interconnection of spinal segments. J Physiol 29:58-96.

Sherrington CS, Laslett EE (1903b) Remarks on the dorsal spino-cerebellar tract. J Physiol 29:188-194.

Skinnider MA, Squair JW, Kathe C, Anderson MA, Gautier M, Matson KJ, Milano M, Hutson TH, Barraud Q, Phillips AA, Foster LJ, La Manno G, Levine AJ, Courtine G (2020) Cell type prioritization in single-cell data. Nat Biotechnol Advance online publication. Retrieved July 20, 2020. doi: 10.1038/s41587-020-0605-1.

Skup M, Gajewska-Woźniak O, Grygielewicz P, Mankovskaya T, Czarkowska-Bauch J (2012) Different effects of spinalization and locomotor training of spinal animals on cholinergic innervation of the soleus and tibialis anterior motoneurons. Eur J Neurosci 36:2679-2688.

Steeves JD, Jordan LM (1980) Localization of a descending pathway in the spinal cord which is necessary for controlled treadmill locomotion. Neurosci Lett 20:283-288.

Stelzner DJ (2008) Short-circuit recovery from spinal injury. Nat Med 14:1920.

Stelzner DJ, Cullen JM (1991) Do propriospinal projections contribute to hindlimb recovery when all long tracts are cut in neonatal or weanling rats? Exp Neurol 114:193-205.

Streeter KA, Sunshine MD, Patel S, Gonzalez-Rothi EJ, Reier PJ, Baekey DM, Fuller DD (2017) Intermittent hypoxia enhances functional connectivity of midcervical spinal interneurons. J Neurosci 37:8349-8362.

Streeter KA, Sunshine MD, Patel SR, Gonzalez-Rothi EJ, Reier PJ, Baekey DM, Fuller DD (2020) Mid-cervical interneuron networks following high cervical spinal cord injury. Respir Physiol Neurobiol 271:103305.

Sunshine MD, Ganji CN, Reier PJ, Fuller DD, Moritz CT (2018) Intraspinal microstimulation for respiratory muscle activation. Exp Neurol 302:93103.

Sweeney LB, Bikoff JB, Gabitto MI, Brenner-Morton S, Baek M, Yang JH, Tabak EG, Dasen JS, Kintner CR, Jessell TM (2018) Origin and segmental diversity of spinal inhibitory interneurons. Neuron 97:341-355.e3.

Sławińska U, Majczyński H, Dai Y, Jordan LM (2012) The upright posture improves plantar stepping and alters responses to serotonergic drugs in spinal rats. J Physiol 590:1721-1736.

Takeoka A, Vollenweider I, Courtine G, Arber S (2014) Muscle spindle feedback directs locomotor recovery and circuit reorganization after spinal cord injury. Cell 159:1626-1639.
Talpalar AE, Bouvier J, Borgius L, Fortin G, Pierani A, Kiehn O (2013) Dualmode operation of neuronal networks involved in left-right alternation. Nature 500:85-88.

Toossi A, Everaert DG, Azar A, Dennison CR, Mushahwar VK (2017) Mechanically stable intraspinal microstimulation implants for human translation. Ann Biomed Eng 45:681-694.

van den Brand R, Heutschi J, Barraud Q, DiGiovanna J, Bartholdi K, Huerlimann M, Friedli L, Vollenweider I, Moraud EM, Duis S, Dominici N, Micera S, Musienko P, Courtine G (2012) Restoring voluntary control of locomotion after paralyzing spinal cord injury. Science 336:1182-1185.

White TE, Lane MA, Sandhu MS, O'Steen BE, Fuller DD, Reier PJ (2010) Neuronal progenitor transplantation and respiratory outcomes following upper cervical spinal cord injury in adult rats. Exp Neurol 225:231-236.

Wiltschko AB, Johnson MJ, Iurilli G, Peterson RE, Katon JM, Pashkovski SL, Abraira VE, Adams RP, Datta SR (2015) Mapping sub-second structure in mouse behavior. Neuron 88:1121-1135.

Zagoraiou L, Akay T, Martin JF, Brownstone RM, Jessell TM, Miles GB (2009) A cluster of cholinergic premotor interneurons modulates mouse locomotor activity. Neuron 64:645-662.

Zhang J, Lanuza GM, Britz O, Wang Z, Siembab VC, Zhang Y, Velasquez T, Alvarez FJ, Frank E, Goulding M (2014) V1 and v2b interneurons secure the alternating flexor-extensor motor activity mice require for limbed locomotion. Neuron 82:138-150.

Zhang Y, Narayan S, Geiman E, Lanuza GM, Velasquez T, Shanks B, Akay T, Dyck J, Pearson K, Gosgnach S, Fan CM, Goulding M (2008) V3 spinal neurons establish a robust and balanced locomotor rhythm during walking. Neuron 60:84-96.

Zholudeva LV, Karliner JS, Dougherty KJ, Lane MA (2017) Anatomical recruitment of spinal V2a interneurons into phrenic motor circuitry after high cervical spinal cord injury. J Neurotrauma 34:3058-3065.

Zholudeva LV, Qiang L, Marchenko V, Dougherty KJ, Sakiyama-Elbert SE, Lane MA (2018a) The neuroplastic and therapeutic potential of spinal interneurons in the injured spinal cord. Trends Neurosci 41:625-639.

Zholudeva LV, Iyer N, Qiang L, Spruance VM, Randelman ML, White NW, Bezdudnaya T, Fischer I, Sakiyama-Elbert SE, Lane MA (2018b) Transplantation of neural progenitors and V2a interneurons after spinal cord injury. J Neurotrauma 35:2883-2903.

Zhong G, Droho S, Crone SA, Dietz S, Kwan AC, Webb WW, Sharma K, Harris-Warrick RM (2010) Electrophysiological characterization of V2a interneurons and their locomotor-related activity in the neonatal mouse spinal cord. J Neurosci 30:170-182. 